\title{
Science Communication by Government Public Relation from A Network Organization Perspective
}

\author{
Shiddiq Sugiono ${ }^{1, *}$ Ummi Salamah $^{2}$
}

\author{
${ }^{1}$ University of Indonesia \\ ${ }^{2}$ University of Indonesia \\ *Corresponding author. Email: sugionoshiddiq@gmail.com
}

\begin{abstract}
Science communication involves delivering scientific information that is not only done by scientists but also by public relations officers at government scientific and technological institutions. The hierarchical mechanism adopted by government agencies is one of the obstacles to the entry of information from various stakeholders. Network organization is a concept of organizational structure that strongly supports the exchange of information between its members. The main objective of this study is to build a conceptual framework of science communication by government public relations from an organizational network perspective so that it can be used as a reference for future research. A similar conceptual framework has been proposed previously but only focuses on the communication aspect and not through an organizational perspective. The systematic literature review produced 28 primary papers from which data was collated to create a conceptual framework. The meta-synthesis technique with the metaethnography approach was used to arrange several concepts in the framework. The results of the study were able to renew the old framework by displaying the collaboration and communication mechanisms of network members and the important role of government public relations as a network manager.
\end{abstract}

Keywords: Science communication, Government Public Relations, Network Organization

\section{INTRODUCTION}

Developments and strides made in science and technology should be shared with the public (Weingart \& Joubert, 2019). The term "dissemination" as used here is a communication process for sharing information on innovations and inventions with certain audiences (Lafrenière, Menuz, Hurlimann, \& Godard, 2013). From the communication perspective, the dissemination of scientific and technological information falls within the scope of science communication. Bhattacharyya (2013) states that science communication refers to communication efforts to bridge the gap between understanding science, the general public, and bringing society closer to modern ways of living.

Government institutions play an important role in how these innovations are communicated to the public. The science communication policy implemented by a government is capable of functioning as a mechanism to connect a government and stakeholders in several countries (Trench \& Miller, 2015). Coordination between the government and its stakeholders cannot be separated from the communication or information exchange process. In relation to the communication process, government public relations plays the significant role of mediator between government agencies and stakeholders (Markus \& Marita, 2015). This paper aims to explore how the communication mechanisms for the exchange of scientific and technological developments that exist between the government and stakeholders.

The connectedness of various stakeholders in a communication network can be explained through a network organization. The implementation of a network organization strongly supports information exchange activities between organizations (Hatch \& Cunliffe, 2013). This, of course, must be carried out with an agreement by network members to follow the rules within which the network agreements must be implemented (Provan \& Kenis, 2008). In addition, governments can become network managers who drive the work direction of network members (Bouckaert, Peters, \& Verhoest, 2010). The government has a significant role in determining success in achieving network level objectives. 
This paper aims to discuss the various concepts involved in science communication by focusing on government organization from a network perspective. The study was hampered by the paucity of literature on science communication conceptual or theoretical frameworks from an organizational perspective. According to Adom, Hussein, and Agyem (2018), a framework is a guideline for future research. In a previous study, Liew et al. (2009) built a science communication framework aimed at biotechnology crops that is not focused on the organization perspective. The adopted communication elements such as message, receiver, sender, channel, effect, and feedback. All concepts in this paper are materials for creating a framework that covers basic aspects of communication.

\section{LITERATURE REVIEW}

\subsection{Development of Science Communication Concepts}

Researches into science communication show that the concept has been institutionalized and has become a global issue, as it focuses on collaboration between institutions in a country (Guenther \& Joubert, 2017). Science communication bridges the gap between science and the general public who do not have an understanding of it. Most people view science as a complex field and, under these circumstances, will be brought closer to understanding it via effective science communication (Bhattacharyya, 2013). In this study, the concept "science" in science communication includes pure sciences such as mathematics, statistics, engineering, technology, medicine and other related fields (Burns, O’Connor, \& Stocklmayer, 2003).

The development of communication elements trigger changes science communication concepts. Bucchi (2013) classifies science communication concepts into science communication 1.0 (SC 1.0) and science communication 2.0 (SC 2.0). The two classifications can be seen from the four parameters described in Table 1. The difference between SC 1.0 and SC 2.0 is in how content is conveyed to audiences from information sources.

Table 1. The Differences between SC 1.0 and SC 2.0

\begin{tabular}{|c|l|l|}
\hline \multicolumn{1}{|c|}{ Parameter } & \multicolumn{1}{|c|}{$\begin{array}{c}\text { Science } \\
\text { Communication } \\
1.0\end{array}$} & $\begin{array}{c}\text { Science } \\
\text { Communication } \\
2.0\end{array}$ \\
\hline $\begin{array}{l}\text { Communication } \\
\text { Model }\end{array}$ & $\begin{array}{l}\text { Mediated, } \\
\text { Filtered }\end{array}$ & $\begin{array}{l}\text { Directly to the } \\
\text { public }\end{array}$ \\
\hline \multirow{3}{*}{ Main Actor } & $\begin{array}{l}\text { Mediators } \\
\text { (scientists, } \\
\text { journalists, } \\
\text { professional } \\
\text { communicators, }\end{array}$ & $\begin{array}{l}\text { Research } \\
\text { institutions, } \\
\text { scientists, digital } \\
\text { media agencies }\end{array}$ \\
\hline
\end{tabular}

\begin{tabular}{|l|l|l|}
\hline & $\begin{array}{l}\text { science } \\
\text { museums) }\end{array}$ & \\
\hline $\begin{array}{l}\text { The relationship } \\
\text { between the } \\
\text { expert and } \\
\text { public } \\
\text { communication }\end{array}$ & $\begin{array}{l}\text { Vertical and } \\
\text { sequential }\end{array}$ & $\begin{array}{l}\text { Horizontal, } \\
\text { takes place } \\
\text { simultaneously } \\
\text { and overlaps }\end{array}$ \\
\hline $\begin{array}{l}\text { Quality } \\
\text { assurance }\end{array}$ & $\begin{array}{l}\text { Editorial brand, } \\
\text { channel } \\
\text { reputation }\end{array}$ & $?$ \\
\hline
\end{tabular}

SC 2.0 offers horizontal communication between the public and scientists or research institutions so as to eliminate the impression that scientists and institutions are exclusive entities. Even so, it faces various challenges regarding the quality assurance of the content delivered, including who is responsible for the published content, collective discussion and content shared on the web network and social media.

Weingart \& Joubert (2019) propose a differentiation of science communication functions. They divided the motives and functions of science communication are divided into Type 1 and Type 2. Type 1 science communication describes an activity designed to educate and inform and involve the public in a two-way dialog. Type 2 science communication describes activities designed to promote and build the image and reputation of scientific organizations and scientists and to legitimize political institutions and their representatives. Type 1 science communication requires communicators to be more sensitive to a particular culture, needs and interests of the audience so that it must present a different content format while Type 2 science communication is mostly focused on attracting the attention of the general public. Public relations must involve both science communication types.

Science communication affects how the public perceive, understand, react to, and accept new technology (Weingart \& Joubert, 2019). Its activities have become important parts of government institutions that make policies in the fields of science, technology, and innovation in Japan so that the policy formation process is more evidence-based and transparent (Kano et al., 2019).

\subsection{Public Relation government In Organization Perspective}

The government, from an organizational perspective, is a group of people who are members of a public institution that has a primary function to provide services to the society (Abdulmelike, 2018; Andriansyah, 2016). The character of government organizations is often seen from two important aspects: bureaucracy, and high level 
of formalization (Hatch \& Cunliffe, 2013). Bureaucratic implementation demands serious attention because it is often one of the impediments to government ability to collaborate flexibly with various parties (Emerson, Nabatchi, \& Balogh, 2011). A high degree of formalization, on the other hand, can be a tool for formal legitimacy to the public or stakeholders (Assenova \& Sorenson, 2017)

The task of public relations is emphasized in twoway dialogical communication with the public. Public relations refers to management functions that seek to build and maintain mutually beneficial relationships between organizations and stakeholders through symmetrical two-way dialog (Kilu \& Akrong, 2014). Because of its communication capabilities, it is important for public relations to occupy strategic positions in organizations. According to Markus and Marita (2015), public relations has an important role to play in an organization's decision-making process because it acts as a facilitator between the public and the organization. In the end, two-way communication will create about social capital between government organizations and the public (Kent \& Taylor, 2014).

Government public relations, from an organizational perspective, can be defined as a group of people who have expertise in building relationships with the society or stakeholders via dialoguing, and achieving set out policy goals. Sari (2015) posits that government public relations needs to communicate and involve certain communities or groups to find current problems and their solutions. Technological developments have brought about dialogical communication into the digital realm. Moreover, it is considered effective because it is able to reach a wider audience and participate in government processes (Graham \& Avery, 2013). Government public relations officers should have the ability to use digital technology so they building relationships and reach a wider public.

\subsection{Government Network Organization Perspective}

Network from an organizational perspective can be seen in the concept of inter-organizational networks where the organizations and stakeholders are connected (Hatch \& Cunliffe, 2013). Stakeholders are defined as actors who interact to form an organizational environment. Participants in an organization's network represent actors or stakeholders while links between actors describe channels for resources, information, or influences. This management practice promotes efficiency by dividing tasks among stakeholders and brings benefits to the division of labor without costs by adding a layer of management or bureaucracy to monitoring and controlling their collective performance.
The assumptions of network-based organizations is non-hierarchical and arranged through collaboration between actors, besides the concept of control is contradictory to network-based organizations (Kenis \& Provan, 2007). The concept of control in network organization refers to the use of a mechanism by network actors to monitor network activities so it will increase the likelihood that network goals can be achieved. Unlike general organizational concepts, network organizations must be managed regardless of the benefits of ownership so that the rules and procedures applied are voluntary. The network organizations formed by the public relations arm of a government institution views information as not possessed by only one stakeholder, but to be used collaboratively by various connected actors.

Networking encourages information exchange, aids the decision-making process, and inspires innovation (Hatch \& Cunliffe, 2013). The exchange of information will occur quickly because information is coming from various directions simultaneously. Networks can foster innovation through increasing information dissemination and integrating various kinds of resources (Hatch \& Cunliffe, 2013). Science communication needs an organized network that allows content innovation to occur rapidly. In addition, the larger a network, the wider its public reach.

Provan \& Kenis (2008) propose a network governance mechanism called Network Administrative Organization. This governance mechanism is suitable for government institutions that are intermediary organizations. Government agencies build relationships between network members and certain formal contracts so that network members have a strong desire to achieve common goals. This is relevant to the framework proposed by Bouckaert, Peters, \& Verhoest (2010) regarding coordination on the mechanism of network organization. In the framework, a central government becomes the network manager for agencies and other organizations in the network that is formed. This mechanism will be the basis for how information can work through relationships between network members.

\section{METHODOLOGY}

This paper uses a systematic literature review (Perry \& Hammond, 2002) with a qualitative meta-ethnography approach. A qualitative approach in meta-ethnography is used to develop a new theory in order to renew existing ones. A systematic literature review involves identifying, appraising, and synthesizing relevant studies, while meta-ethnography aims to synthesize various studies from several perspectives or methodologies (Florczak, 2019). Meta-ethnographic synthesis makes it possible to take concepts that are implicitly linked and arranged in a theoretical model (Greenwood \& Mackenzie, 2010). The meta-ethnographic approach is used to describe and 
integrate cross-studies to form a new understanding and perspective (Mcdermott, Graham, \& Hamilton, 2004).
Table 2 is a description of each phase that will be implemented in this study.

Table 2. Methodology Steps

\begin{tabular}{|c|c|}
\hline Steps & Description \\
\hline $\begin{array}{l}\text { Identification of research } \\
\text { questions }\end{array}$ & $\begin{array}{l}\text { 1. How is science communication carried out by government public relations? } \\
\text { 2. How is science communication carried out in organizational networks? } \\
\text { 3. How do government public relations use the media in conducting science } \\
\text { communication? } \\
\text { 4. How are the government public relations science communication activities from a } \\
\text { network organization perspective? }\end{array}$ \\
\hline $\begin{array}{l}\text { Developing research protocol for } \\
\text { systematic review }\end{array}$ & $\begin{array}{l}\text { Strategies in conducting searches are built through keyword determination and } \\
\text { synonyms from the focus of the study. Keywords used in literature search are: } \\
\text { science communication, government public relations, network organizations, } \\
\text { government organizations. }\end{array}$ \\
\hline $\begin{array}{l}\text { Determining the location of } \\
\text { research results database as the } \\
\text { search area }\end{array}$ & $\begin{array}{l}\text { A literature search was performed on Google Scholar to enlarge the range of } \\
\text { findings. }\end{array}$ \\
\hline $\begin{array}{l}\text { Selection of relevant research } \\
\text { result }\end{array}$ & $\begin{array}{l}\text { The paper selection procedure was performed by speed reading primary study } \\
\text { candidates. Speed reading is reading the abstract section of the available papers. }\end{array}$ \\
\hline $\begin{array}{l}\text { Choose quality research results } \\
\text { Extraction }\end{array}$ & $\begin{array}{l}\text { Identification can be done by applying an inclusion and exclusion criteria. This will } \\
\text { guarantee that the paper used is appropriate in the context of the study. } \\
\text { Inclusion Criteria: } \\
\text { 1. Literature on the implementation of science communication in government public } \\
\text { relations through a network organization perspective. } \\
\text { Exclusion Criteria: } \\
\text { 1. Literature on science communication. } \\
\text { 2. Literature on science communication in government public relations. } \\
\text { 3. Literature on government public relations. } \\
\text { 4. Literature on the network organization. } \\
\text { 5. Literature on public relations governance in network organizations. } \\
\text { 6. Literature on the use of science communication platforms. }\end{array}$ \\
\hline $\begin{array}{l}\text { Extraction of data from individual } \\
\text { studies }\end{array}$ & $\begin{array}{l}\text { The literature selection process yielded } 28 \text { documents from which data was } \\
\text { extracted. }\end{array}$ \\
\hline $\begin{array}{l}\text { Synthesis of the results via meta- } \\
\text { analysis (if possible) or the } \\
\text { narrative method (if not possible) }\end{array}$ & $\begin{array}{l}\text { The results of literature review will be explored in relationship with several concepts } \\
\text { that support this research. Concept synthesis uses a meta-ethnographic approach. }\end{array}$ \\
\hline Present findings & Write down the systematic review result. \\
\hline
\end{tabular}

The use of the meta-ethnographic approach in this study is intended to formulate and propose a conceptual model of scientific communication by a government's public relations arm from the perspective of organizational networks. Table 3 contains 28 literatures grouped by keywords or research themes and which are the basis of the conceptual framework.
Table 3. Literature Selection Result

\begin{tabular}{|l|l|}
\hline \multicolumn{1}{|c|}{ Keyword } & \multicolumn{1}{|c|}{ Literature } \\
\hline \multirow{3}{*}{$\begin{array}{l}\text { Science } \\
\text { Communication }\end{array}$} & $\begin{array}{l}\text { Burns, O'Connor, and Stocklmayer } \\
\text { (2003), Bubela et al. (2009), Men \& } \\
\text { (2013), Jucan and Jucan (2014), } \\
\end{array}$ \\
& Fischhoff (2014), Balcom (2015), \\
\hline
\end{tabular}




\begin{tabular}{|l|l|}
\hline & $\begin{array}{l}\text { Weingart and Guenther (2016), } \\
\text { Taşkıran (2016), Braha (2017), } \\
\text { Gascoigne and Metcalfe (2017), } \\
\text { Guenther and Joubert (2017), } \\
\text { Weingart and Joubert (2019), Kano } \\
\text { et al. (2019) }\end{array}$ \\
\hline $\begin{array}{l}\text { Government } \\
\text { Organization }\end{array}$ & $\begin{array}{l}\text { Assenova and Sorenson (2017), } \\
\text { Abdulmelike (2018) }\end{array}$ \\
\hline & $\begin{array}{l}\text { Kenis and Provan (2007), Provan } \\
\text { and Kenis (2008), Emerson, }\end{array}$ \\
$\begin{array}{l}\text { Network } \\
\text { Organization } \\
\text { and Lemaire (2012), Linders (2012), } \\
\text { Cristofoli and Markovic (2016),, } \\
\text { Ghezzi, Gabelloni, Martini, and } \\
\text { Natalicchio (2017) }\end{array}$ \\
\hline $\begin{array}{l}\text { Government } \\
\text { Public } \\
\text { Relationship/Pu } \\
\text { blic Relation }\end{array}$ & $\begin{array}{l}\text { Taylor (2014), Sari (2015), Mujiati, } \\
\text { Kusuma, and Paselle (2015) }\end{array}$ \\
\hline
\end{tabular}

The results of the concept relationship will be displayed in the conceptual framework at the end of the discussion. The use of systematic literature review methods will provide latest research findings and provide recommendations to policy makers that are relevant to the model formed (Napitupulu, 2019).

\section{RESULT AND DISCUSSION}

\subsection{Science Communication in Government Public Relations}

Government public relations have the duty to deliver information about government policies, actions, programs and activities (Mujiati et al., 2015). This also applies to various government institutions in the fields of science and technology, on the technical and policy planning aspects. Science communication is an effort made by government institutions to help the public understand the scientific and technological developments it is making (Bhattacharyya, 2013; Weingart \& Joubert, 2019). In this article, government public relations refers to communication practitioners in government institutions that engage in scientific and technological research.

The success of science communication is influenced by multi-disciplinary experts. Fischhoff (2014) states that communication practitioners play an important role in building channels among researchers who are sources of scientific content for the public. Communication practitioners have the duty to translate the research result, connect scientists to audiences, and build opportunities for public involvement. Science communication requires the public relations role in promotional activities and persuasive communication so that it can create content that looks interesting (Weingart \& Joubert, 2019).

Science communication is focused on the credibility of information that is delivered to the public. Credibility refers to the judgment made by the recipient of the message about the trustworthiness of a communicator (Coy, 2001). Academic scientists and science journalists are considered highly credible in delivering scientific content (Weingart \& Guenther, 2016). Government public relations arms need to work together in order to increase public understanding of science (PUS).

Intensive science communication between scientists and the public builds Public Engagement with Science. The concept allows scientists and the public to be able to work together and enable people of various backgrounds and scientific expertise to contribute their perspectives, ideas and knowledge in designing scientific questions or discussing scientific controversies (Jucan \& Jucan, 2014). From an organizational perspective, science communication requires communication experts other than scientists so that intensive interaction with the public can be established. A good division of tasks between scientists and communication practitioners in an organization is expected to be able to streamline work results.

\subsection{Network Perspective of Science Communication}

The primary goal of organizational work based on networks is for interconnected stakeholders to work together. Government in this case needs to rely on public relations because they have the ability to build relationships with stakeholders so that network development can be done more effectively. Government public relations officers who conduct science communication must map various kinds of stakeholders if they want to adopt a network organization. Burns et al. (2003) map some of the actors involved in science communication: government, media, scientists, policy makers, scientific community. All stakeholders are actors or network members who have important roles in the success or survival of the network. The network success in this article is limited to disseminating information to the public while the survival of the organization refers to how the needs of network members for information needed as a basis for media content can be fulfilled.

Government public relations plays a role in keeping the public informed about issues, problems, and actions at every level of government. Public relations practitioners must focus on building positive and longterm relationships between stakeholders. They need to build mutual understanding, trust and intentions through 
dialog and maintain a positive relationship (Taşkıran, 2016). Government institutions have a role as network creators, network managers, and network participants (Bouckaert et al., 2010). Community relations must be carried out by the organization in a bid to form good relations with the surrounding community.

Scientists also have an important role in science communication (Jucan \& Jucan, 2014). In this study, scientists are part of relevant government institutions. In network organizations, the necessary resources can be distributed among several members so that not only one organization or member produces the product but the overall network is a content provider or producer (Hatch $\&$ Cunliffe, 2013). The passage of information through scientists is expected to assure the credibility of the content that will be delivered to the public. They can verify information that flows on the network.

The concept of Communities of Practice (CoP) is an interpretation of the community from a communication perspective. CoP is a group of people who share an interest, a focus or several problems and interact regularly in order to deepen their knowledge and expertise and to learn how to do things better (Mohajan, 2017). The scientific community can play an important role in promoting science communication and making science communication a part of their activities (Braha, 2017). The greater the growth of knowledge or information produced by the CoP will attract the attention of new members (Lima, Carvalho, \& Laboissiere, 2010) so it does not close the possibility that information flowing to government public relations will also increase as CoP size increases.

One feature of network organizations is citizen science, a concept that allows professional scientists to provide and receive information from an amateur public as voluntary participants in research (Dowthwaite \& Sprinks, 2019). This concept is strongly supported by the emergence of internet technology that is able to bring together scientists and amateurs. One contribution that can be made by the amateur public is the provision of large quantities of data through the internet (Bonney et al., 2009). The results of this joint project can be published in a variety of activities, presentations in schools, or even presenting them in science club (Dowthwaite \& Sprinks, 2019). In this case, the government must create a platform where people can interact with each other.

The media agency can connect scientists who want to share scientific information with the public. The media in this case will not only cover television or print-based media and the internet. Films, science centers, science galleries, scientific events or festivals, and museums can become tools for science communication. The media to be used as tools to communicate scientific developments requires government public relations to innovate so that the delivery of scientific information is not boring to the public (Burns et al., 2003). Various media are needed to cater to various personality types, learning styles, social backgrounds, and audiences to aid education in understanding science (Burns et al., 2003).

Policymakers are elected officials and part of the government institution that is responsible for creating regulations (Ringold, Holla, Koziol, \& Srinivasan, 2012). Science communication to policy makers can be done through formal activities such as conference presentations, public talks or events involving certain communities so that explanations about science can be conveyed in more depth and with certain language (Cooke, Gallagher, Nguyen, Canada, \& Skubel, 2017). Effective science communication with policy makers will lead to evidence-based policies (Rodari, Bultitude, \& Desborough, 2012).

Gascoigne \& Metcalfe (2017) states that scientists, media, industry, government must have a common goal to increase public awareness about science and technology. Industry employ scientists to develop new technological products (Burns et al., 2003). This is relevant because an important role of science communication is to inform the public on the development of new technologies (Scholten, Hoven, Cuppen, \& Flipse, 2016). Government public relations should not forget that the industry is one of the users of scientific and technological products, so that content about the application of science can be presented to public.

\subsection{Utilization Of Social Media and Platform}

From the perspective of network organizations, collaboration is a form of communication between network members in order to achieve common goals. This collaboration can be either offline or online. Online collaboration is considered more effective in achieving goals because it is able to attract various parties who have the same interests, eases the exchange of information, make group decisions on a large scale and integrate various individual contributions (Linders, 2012). Communication platforms that support interactivity are the backbone of online collaboration. Social media platforms have become good communication platforms that support collaboration between actors.

The use of social media is a modern communication trend that offers various benefits to its users. In the organizational context, the benefits attributable to social media use is an increase in public engagement, directing information and maintaining public relations with an organization (Men \& Tsai, 2013). Kent \& Taylor (2014) state that social capital emerge as a result of communicative relationships between organizations and their public. Social capital refers to benefits arising from interaction and ideology that is shared with individuals 
and organizations acting together to achieve collective goals (Kent \& Taylor, 2014). Based on these two concepts, social media has become an effective communication tool for science communication activities because network members will get feedback in the form of social capital from the public and stakeholder.

Eperen \& Marincola (2011) posit that groups of scientists need to use social media to communicate the results of their research. Communicating through social media is crucial to distributing scientific information from experts to the public. In this study, the scientist is someone who works for a government institution, so the obligation to distribute scientific information through social media is also a duty of the public relations arms of relevant institutions. Scientists and science journalists can use blogs as tools to communicate with the public about the background and context of the field of research that is being worked on. Science blogs can have a dialog with their readers in an informal language style (Bubela et al., 2009). Through the blog, information is directly sourced from content providers; there is no filtration from the organizational hierarchy.

\subsection{Proposed Framework}

The conceptual framework refers to a set of concepts, assumptions along with relationships to be proposed as a basis for understanding certain problems, subjects or phenomena. Through the framework, a problem can be seen from a certain perspective (Herring, 2017). Fig. 1 is a framework built by synthesizing some of the concepts discussed earlier.

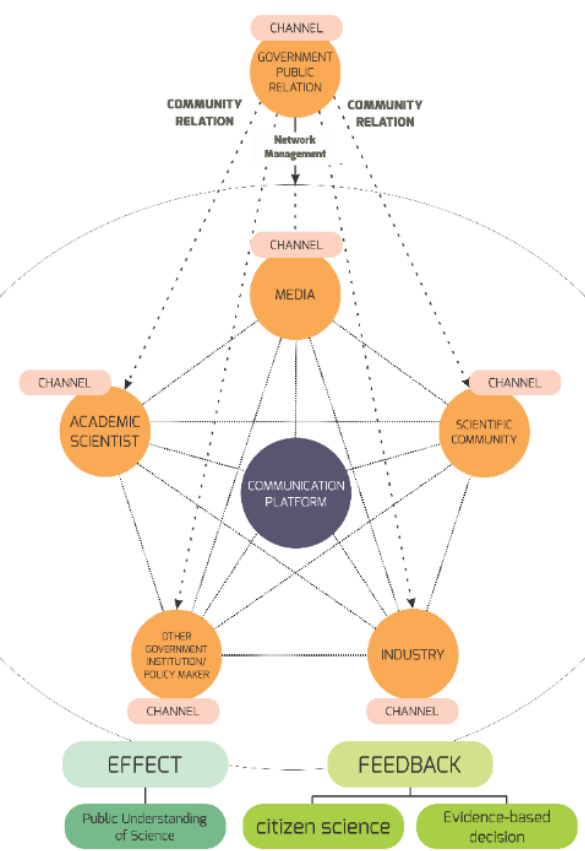

Figure 1. Science communication framework by government public relations on a network perspective
(Source: Bouckaert et al., 2010; Burns et al., 2003; Dowthwaite \& Sprinks, 2019; Eperen \& Marincola, 2011; Hatch \& Cunliffe, 2013; Rodari et al., 2012)

Community relations is the main key for the framework because network organization is basically about how to build working relationships between each stakeholder and how information can move through the relationships that are formed. The sharing of resource ownership is expected to amplify the acceleration of information exchange. In addition, the absence of a hierarchy in network organization causes the output produced by one member to be the output of all network members. This is because network members are already bound by formal contracts approved by each member of the network. The big task of government public relations is to hold various platforms that are able to strengthen relations between network members and facilitate the process of information exchange. The formation of a network organization is essentially an alternative to a hierarchical mechanism, so that government agencies as network enabler needs to become an intermediary organization to offer the contracts to potential network members. The contract, of course, is a mechanism for coordination or information sharing without the existence of a specific hierarchical mechanism because all activities are carried out voluntarily so that common goals can be achieved. The contract is the implementation of a high level formalization of government agencies to its stakeholders.

Science communication in practice still utilizes traditional media and new media. Scientific information can be accepted by the public from various actors incuding scientific, public relations and scientific journalists and through various channels such as newspapers, television press releases and social media (Weingart \& Guenther, 2016). Social media platforms can be used to build collaborative content, and maintaining the credibility of published information. Social media platforms have become information channels that play an important role in modern science communication because they open opportunities for dialog between the public and network members.

Public relations as the center of the network must be able to create and develop a platform to maintain and strengthen community relationships among network members. The concept of the platform itself can be seen from various perspectives such as media networks (Memon \& Meyer, 2017), businesses (Jeong \& Kim, 2016) and others. In the proposed framework, the platform refers to a collection of components or methods that allow network members to develop content effectively through an interface. Scientists play an important role as actors who verify the content created so that its credibility is maintained. The components of online media, traditional media, formal and informal activities need to be maximized by all network members. 
In this framework, maximization is so the media can be used as communication tools that support the sustainability of interaction so that social capital can emerge from relationships that are built.

Public Understanding of Science (PUS) occurs when science communication activities are carried out. While the feedback obtained from science communication with the public is expected to be collaborative. The link between policy makers and scientists will support the formation of evidence-based policy. The mechanism is expected to be a continuous solution to public problems. PUS becomes the initial output of science communication activities while public engagement is the final output because the public not only understands but is involved in scientific development.

\section{CONCLUSION}

This study proposes a synthesis between science communication concepts with network organizations to support disseminating scientific content in a conceptual framework. The proposed framework explains how various actors interact with each other in science communication activities. Compared to the framework developed previously by Liew et al. (2009), the results of this study are able to discuss the information transfer mechanism of each science communication actor. By focusing on the concept of organizational networks, the proposed framework has mapped government public relations stakeholders in carrying out science communication activities. The role of government public relations in this framework is that of a network manager so that the network structure remains stable and network members remain focused on achieving common goals. The communication platform is an important element in this framework because it is a medium for collaboration. Through this framework, the public contribution in developing and solving scientific problems becomes greater as all actors have the same goal.

The proposed framework is also expected to be a reference for future studies on synthesized science communication concepts for government institutions that want to implement science communication programs. Future studies are expected to be able to develop collaborating science communication with a variety of contemporary concepts. This study was limited as not all aspects of science communication are explored within the framework. In-depth research on the credibility of messages from science communication needs to be done to complete this framework.

\section{REFERENCES}

[1] Adom, D., Hussein, E.K. and Agyem, J.A. (2018). 'International journal of scientific research theoretical and conceptual framework. mandatory Ingredients Dickson Adom * Emad Kamil
Hussein'. International Journal of Scientific Research, 7(1), pp. 438-441.

[2] Andriansyah, A. 2016. 'Administrasi dalam Kajian dan Analisa'. [Dr. Moestopo Beragama]. Retrieved from https://moestopo.ac.id/wpcontent/uploads/2016/05/Administrasi-

Pemerintahan-Daerah-Dalam-Analisa-Oleh-Dr.Andriansyah.-M.Si_.pdf. Fakultas Ilmu Sosial dan Ilmu Politik Universitas Prof, Jakarta.

[3] Assenova, V.A. and Sorenson, O. (2017) 'Legitimacy and the benefits of firm formalization'. Organization Science, 28(5), pp. 804-818. https://doi.org/10.1287/orsc.2017.1146.

[4] Balcom, B. (2015). 'Improving crowdsourcing and citizen science as a policy mechanism for NASA'. New Space, 3(2), pp. 98-116. https://doi.org/10.1089/space.2015.0017.

[5] Bhattacharyya, K.K. (2013). 'Science communication as a tool for development', Global Media Journal-Indian Edition, 4(2), pp. 1-10.

[6] Bonney, R., Cooper, C.B., Dickinson, J., Kelling, S., Phillips, T., Rosenberg, K.V. and Shirk, J. (2009). 'Citizen science: A developing tool for expanding science knowledge and scientific literacy'. BioScience, 59(11), pp. 977-984. https://doi.org/10.1525/bio.2009.59.11.9.

[7] Bouckaert, G., Peters, B.G. and Verhoest, K. 2010 The coordination of public sector organizations: shifting patterns of public management. Palgrave Macmillan, Eastbourne.

[8] Braha, J. (2017). 'Science communication at scientific societies'. Seminars in Cell and Developmental Biology, 70, pp. 85-89. https://doi.org/10.1016/j.semcdb.2017.05.010.

[9] Brossard, D. (2013). 'New media landscapes and the science information consumer'. Proceedings of the National Academy of Sciences of the United States of America, 110 Suppl. 3, 14096-14101. https://doi.org/10.1073/pnas.1212744110, PubMed: 23940316

[10] Bubela, T., Nisbet, M.C., Borchelt, R., Brunger, F., Critchley, C., Einsiedel, E., Geller, G., Gupta, A., Hampel, J., Hyde-Lay, R., Jandciu, E.W., Jones, S.A., Kolopack, P., Lane, S., Lougheed, T., Nerlich, B., Ogbogu, U., O'Riordan, K., Ouellette, C., Spear, M., Strauss, S., Thavaratnam, T. Willemse, L. and Caulfield, T. (2009). 'Science communication reconsidered'. Nature Biotechnology, 27(6), pp. 514-518. https://doi.org/10.1038/nbt0609-514, PubMed: 19513051 
[11] Bucchi, M. (2013). 'Style in science communication'. Public Understanding of Science, 22(8), pp. 904-915. https://doi.org/10.1177/0963662513498202, PubMed: 23969941.

[12] Burns, T.W., O’Connor, D.J. and Stocklmayer, S.M. (2003). 'Science Communication: A Contemporary Definition'. Public Understanding of Science, 12(2), pp. 183-202. https://doi.org/10.1177/09636625030122004.

[13] Callison, C. (2001). 'Do PR practitioners have a PR problem ?: the effect of associating a source With public relations and client- negative news on audience perception of credibility'. Journal of Public Relations Research, 13(3), pp. 219-234. https://doi.org/10.1207/S1532754XJPRR1303_2.

[14] Cooke, S., Gallagher, A.J., Nguyen, V.M., Canada, N.R. and Skubel, R. 2017 Considerations for effective science communication, (March). https://doi.org/10.1139/facets-2016-0055.

[15] Cristofoli, D. and Markovic, J. 2016 How to make public networks really work, 94(1). https://doi.org/10.1111/padm.12192.

[16] Dowthwaite, L. and Sprinks, J. (2019). 'Citizen science and the professional-amateur divide: lessons from differing online practices'. Journal of Science Communication, 18(1), pp. 1-18. https://doi.org/10.22323/2.18010206.

[17] Emerson, K., Nabatchi, T. and Balogh, S. 2011 An integrative framework for collaborative governance, (June 2009), 1-29. https://doi.org/10.1093/jopart/mur011.

[18] Eperen, L. Van and Marincola, F.M. (2011). 'How scientists use social media to communicate their research'. Journal of Translational Medicine, 9(1), p. 199. https://doi.org/10.1186/1479-5876-9-199.

[19] Fischhoff, B. (2013). 'The sciences of science communication'. Proceedings of the National Academy of Sciences of the United States of America, 110 Suppl. 3, 14033-14039. https://doi.org/10.1073/pnas.1213273110, PubMed: 23942125.

[20] Florczak, K.L. (2019). 'Meta-aggregation: just what is it?'. Nursing Science Quarterly, 32(1), p. 11. https://doi.org/10.1177/0894318418807933.

[21] Gascoigne, T. and Metcalfe, J. (2017). 'The emergence of modern science communication in Australia'. Journal of Science Communication, 16(3), pp. 1-18. https://doi.org/10.22323/2.16030201.
[22] Ghezzi, A., Gabelloni, D., Martini, A. and Natalicchio, A. (2018). 'Crowdsourcing: a review and suggestions for future research'. International Journal of Management Reviews, 20(2), pp. 343363. https://doi.org/10.1111/ijmr.12135.

[23] Graham, M. and Avery, E.J. (2013). 'Government public relations and social media : an analysis of the perceptions and trends of social media use at the Local Government level'. Public Relations Journal, 7(4), pp. 1-21. Retrieved from https://prjournal.instituteforpr.org/wpcontent/uploads/2013GrahamAvery.pdf.

[24] Greenwood, N. and Mackenzie, A. (2010). 'Informal caring for stroke survivors: metaethnographic review of qualitative literature'. Maturitas, 66(3), pp. 268-276. https://doi.org/10.1016/j.maturitas.2010.03.017.

[25] Guenther, L. and Joubert, M. (2017). 'Science communication as a field of research: identifying trends, challenges and gaps by analysing research papers'. Journal of Science Communication, 16(2), pp. 1-19. https://doi.org/10.22323/2.16020202.

[26] Hatch, M.J. and Cunliffe, A.L. 2013 Organization theory: modern, symbolic and postmodern perspectives (3rd ed)Oxford. https://doi.org/10.1017/CBO9781107415324.004.

[27] Herring, B. (2017). 'A'. Sexual Addiction and Compulsivity, 24(4), pp. 242-247. https://doi.org/10.1080/10720162.2017.1394947.

[28] Jeong, Y. and Kim, S. (2016). 'Critical success factors for IPTV growth: a case study approach'. International Journal of Advanced and Applied Sciences, 2(12), pp. 58-66. Retrieved from http://www.science-gate.com/IJAAS/Articles/20152-12/11 2015-2-12-pp.58-66.pdf.

[29] Jucan, M.S. and Jucan, C.N. (2014). 'The power of science communication'. Procedia - Social and Behavioral Sciences, 149, pp. 461-466. https://doi.org/10.1016/j.sbspro.2014.08.288.

[30] Kano, K., Kudo, M., Yoshizawa, G., Mizumachi, E., Suga, M., Akiya, N., ... Katsuya TakanashiKei Kano, Mitsuru Kudo, Go Yoshizawa, Eri Mizumachi, Makiko Suga, Naonori Akiya, Kuniyoshi Ebina, Takayuki Goto, Masayuki Itoh, Ayami Joh, Haruhiko Maenami, Toshifumi Minamoto, Mikihiko Mori, Yoshitaka Morimura, Tamaki Motoki, A. N. and K. T. (2019). How science, technology and innovation can be placed in broader visions - Public opinions from inclusive public engagement activities. Journal OfScience Communication, 18(03), 1-19. https://doi.org/https://doi.org/10.22323/2.18030202 
[31] Kenis, P. and Provan, K.G. (2006). 'The control of public networks'. International Public Management Journal, 9(3), 227-247. https://doi.org/10.1080/10967490600899515.

[32] Kent, M. and Taylor, M. 2014. 'Social media in public relations: reflections on extending and narrowing relationships'. Retrieved from https://www.researchgate.net/publication/28798241 3_Social_Media_in_Public_Relations_Reflections_ on_Extending_and_Narrowing_Relationships/link/ 567ae88208aebccc4dfd643c/download, In International Forum on Public Relation and Advertising.

[33] Kilu, R.H. and Akrong, B.S. (2014). 'Gender, community affairs and public relations practice in Ghanaian mines: a socio-linguistic study of gender and language nuances'. Journal of Business Research, 8. Retrieved from https://www.divaportal.org/smash/get/diva2:987834/FULLTEXT01. pdf.

[34] Lafrenière, D., Menuz, V., Hurlimann, T. and Godard, B. (2013). 'Knowledge dissemination interventions A literature review'. SAGE Open, 3(3), pp.

$1-14$. https://doi.org/10.1177/2158244013498242.

[35] Liew, K.C., Trade, A., Commission, I., Karembu, M. and Arujanan, M., Choudhary, M.I. 2009. 'ISAAA Brief 40 " Communicating Crop Biotechnology : stories from Stakeholders " i s a a a ISAAA Briefs brief 40 Communicating Crop Biotechnology: stories from Stakeholders Edited by Manager, Global Knowledge Center on Crop Biotechnology Mariechel J . Na'. Retrieved from https://www.isaaa.org/resources/publications/briefs/ 40/download/isaaa-brief-40-2009.pdf.

[36] Lima, J., Carvalho, C. and Laboissiere, A.P. (2010). 'Knowledge management in virtual communities of practice'. In $\mathrm{P}$ Virtanen \& $\mathrm{N}$ Helander (Eds.): Knowledge Management. In Knowledge Management (pp. 93-110) Tech Publications, Croatia. https://doi.org/10.5772/9553.

[37] Linders, D. (2012). 'From e-government to wegovernment: defining a typology for citizen coproduction in the age of social media'. Government Information Quarterly, 29(4), pp. 446454. https://doi.org/10.1016/j.giq.2012.06.003.

[38] Markus, M.M.A. and Marita, V. (2015). 'The contribution of public relations to organizational decision making: insights from the literature'. Journal of Public Relation, 9(2).

[39] Mcdermott, E., Graham, H. and Hamilton, V. (2004). 'Experiences of being a teenage mother in the UK: A report of a systematic review of qualitative studies Institute for Health Research Lancaster University MRC Social and Public Health Sciences unit University of Glasgow Glasgow, (March)'. Retrieved from http://www.sphsu.mrc.ac.uk/Evidence/Research/Re view 10/SR. Executive Summary.pdf.

[40] Memon, A.B. and Meyer, K. (2017). 'Why we need dedicated web-based collaboration platforms for inter-organizational connectivity? A research synthesis'. International Journal of Information Technology and Computer Science, 9(11), pp. 111. https://doi.org/10.5815/ijitcs.2017.11.01.

[41] Men, L.R. and Tsai, W.S. (2013). 'Toward an integrated model of public engagement on corporate social networking sites: antecedents, the process, and relational outcomes'. International Journal of Strategic Communication, 7(4), pp. 257273. https://doi.org/10.1080/1553118X.2013.822373.

[42] Mohajan, H. (2017). 'Roles of communities of practice for the development of the society'. Journal of Economic Development, Environment and People, 6(3), pp. 1-23.

[43] Mohammed, A.A. (2018). 'How do teams become effective? A literature review and implication for Ethiopia'. African Journal of Business Management, 12(16), pp. 501-508. https://doi.org/10.5897/AJBM2016.8189.

[44] Mujiati, M., Kusuma, A.R. and Paselle, E. (2015) 'Peran humas Sekretariat DPRD dalam Menjalin hubungan Sinergis antara media dengan DPRD kabupaten Bulungan'. Jurnal Administrative Reform' 3(4), pp. 441-451. Retrieved from http://ejournals.unmul.ac.id/index.php/JAR/article/view/58 $3 / 533$.

[45] Napitupulu, D. (2016). Jurnal Bina Praja eGovernment Maturity Model. Jurnal Bina Praja. 'e-Government Maturity Model Based on Systematic Review and Meta-Ethnography Approach'. Jurnal Bina Praja, 8(2), pp. 263-275. https://doi.org/10.21787/jbp.08.2016.263-275.

[46] Perry, A. and Hammond, N. (2002). 'Systematic reviews: the experiences of a $\mathrm{PhD}$ student'. Psychology Learning and Teaching, 2(1), pp. 3235. https://doi.org/10.2304/plat.2002.2.1.32.

[47] Provan, K.G. and Kenis, P. (2008). 'Modes of network governance: structure, management, and effectiveness'. Journal of Public Administration Research and Theory, 18(2), 229-252. https://doi.org/10.1093/jopart/mum015. 
[48] Provan, K.G. and Lemaire, R.H. (2012). 'Core concepts and key ideas for understanding public sector organizational networks: using research to inform scholarship and practice'. Public Administration Review, 72(5), 638-648. https://doi.org/10.1111/j.1540-6210.2012.02595.x.

[49] Ringold, D., Holla, A., Koziol, M. and Srinivasan, S. 2012. 'Citizens and service delivery: assessing the use of Social accountability approaches in human development'. Retrieved from https://openknowledge.worldbank.org/handle/1098 6/2377. The World Bank, Washington DC.

[50] Rodari, P., Bultitude, K. and Desborough, K. (2012). 'Science communication between researchers and policy makers . Reflections from a European project'. Journal of Science Communication, 11(3), pp. 1-8. https://doi.org/10.22323/2.11030307.

[51] Sari, N. 2015. Retrieved from https://www.academia.edu/attachments/53363378/d ownload file?st=MTU2NTIzMzk0NiwxMDMuMT IxLjE2LjMsOTY4OTYzNjM\%3D\&s=swp-toolbar, In. International Conference on Demcracy and Accountability International Conference on Democracy and Accountability (ICoDA).

[52] Scholten, V., Hoven, J. Van Den, Cuppen, E. and Flipse, S. (2016). 'Science communication and Responsible Research and Innovation. How can they complement each other?' Journal of Science Communication, 15(6), pp. 1-7. https://doi.org/10.22323/2.15060304.

[53] Taşkıran, H.B. (2016). 'Government public relations in turkey: Social Media Usage of Turkish Ministries in relationship building'. Online Journal of Communication and Media Technologies, 6(1), pp. 48-63. Retrieved from https://www.ojcmt.net/download/governmentpublic-relations-in-turkey-social-media-usage-ofturkish-ministries-in-relationship.pdf.

[54] Trench, B. and Miller, S. (2015). Policies and practices in supporting scientists, public communication through training, (December). https://doi.org/10.1093/scipol/scs090.

[55] Weingart, P. and Guenther, L. (2016). 'Science communication and the issue of trust'. Journal of Science Communication, 15(5), pp. 1-11. https://doi.org/10.22323/2.15050301.

[56] Weingart, P. and Joubert, M. (2019). 'The conflation of motives of science communication causes, consequences, remedies'. Journal of Science Communication, 18(3), pp. 1-13. https://doi.org/10.22323/2.18030401. 